\title{
O DIREITO FUNDAMENTAL À IDENTIDADE GENÉTICA E A CONDUÇÃO COERCITIVA PARA REALIZAÇÃO DE EXAME DE DNA: UM DEBATE NECESSÁRIO
}

\author{
THE FUNDAMENTAL RIGHT TO GENETIC IDENTITY \\ AND THE COERCITIVE CONDUCTION TO DNA TESTING: \\ A NECESSARY DEBATE
}

\author{
FABRÍCIO CASTAGNA LUNARDI ${ }^{1}$
}

\begin{abstract}
RESUMO: O presente artigo científico tem por escopo desenvolver o conteúdo do direito fundamental à identidade genética e verificar se, diante do paradigma atual do direito, os fundamentos da decisão do STF no HC 71373/RS, de 1994, que impediu a condução coercitiva do investigado para realização de exame de DNA, ainda se sustentam ou, ao contrário, se tais fundamentos merecem ser revistos. Para tanto, analisam-se a referida decisão e também os julgamentos posteriores da Suprema Corte sobre essa matéria. Após, discorre-se sobre o novo paradigma do direito, que implicará uma nova reflexão sobre o tema. Demonstra-se que se está diante de um caso difícil e que a decisão precisa ser construída argumentativamente. $\mathrm{Na}$ sequência, desenvolve-se o conteúdo do direito fundamental à identidade genética. Por fim, analisa-se reflexivamente, à luz do princípio da proporcionalidade, o conflito inerente que se estabelece entre os direitos fundamentais e conclui-se pela possibilidade e constitucionalidade da condução coercitiva do investigado para realização do exame de DNA.

PALAVRAS-CHAVE: Direitos Fundamentais; Identidade Genética; Condução Coercitiva; Exame de DNA.

ABSTRACT: This scientific paper has the purpose to develop the content of the fundamental right of genetic identity and to verify, according to the current paradigm of law, if the foundations of the Supreme Court decision in the HC 71373/RS, from 1994, which prevented the coercitive conduction of the investigated to DNA testing, still remains or, on the contrary, if the foundations
\end{abstract}

\footnotetext{
Artigo recebido em 23.09.2012. Pareceres emitidos em 29.10.2012 e 10.11.2012.

Artigo aceito para publicação em 23.06.2013.

${ }^{1}$ Mestrando em Direito Constitucional pela Universidade de Brasília (UnB). Bacharel em Direito e Especialista em Direito Civil pela UFSM. Professor dos Cursos de Pós-Graduação Lato Sensu da Escola Superior da Magistratura do Distrito Federal, do Instituto Brasilense de Direito Público (IDP) e da Escola de Administração Judiciária do TJDFT. Juiz de Direito Substituto da Justiça do Distrito Federal e Territórios. fabricioclunardi@yahoo.com.br
} 
deserve to be reviewed. Toward, this decision and also the subsequent judgments of the Supreme Court on this matter are analyzed. After that, the new paradigm of law is discussed, and also its influence on the subject. It is shown that DNA testing is a hard case and that the decision needs to be built argumentatively. Further, it develops the content of the fundamental right to genetic identity. Finally, it is analyzed reflectively, under the principle of proportionality, the inherent conflict that arises between fundamental rights and it is concluded for the possibility and for the constitutionality of coercitive conduction to DNA testing.

KEYWORDS: Fundamental Rights; Genetic Identity; Coercitive Conduction; DNA Testing.

SUMÁRIO: Introdução; 1. O Estado da Questão na Jurisprudência do STF; 1.1 A Decisão Paradigma do HC 71373/RS, de 10.11.1994; 1.2 A Indicação de uma nova Perspectiva do STF; 1.3 A Manifestação Expressa do STF sobre a Necessidade de Rediscussão da Matéria: A imprescindibilidade de condução coercitiva do investigado para realização do exame de DNA em nome do direito fundamental à identidade genética do ser; 2. O Paradigma Atual da Teoria do Direito: A necessidade de uma nova reflexão acerca da condução coercitiva do suposto pai; 3. O Caso da Condução Coercitiva do Investigado ao Exame de DNA - Um caso difícil; 4. As Normas Infraconstitucionais e a Repetição Jurisprudencial não Autoconsciente; 5. O Direito Fundamental à Identidade Genética no Ordenamento Jurídico Brasileiro; 6. Dignidade da Pessoa Humana e Direito Fundamental à Identidade Genética da Criança versus Liberdade, Integridade Física e Interesse do suposto pai de não produzir prova contra si mesmo; Conclusão; Referências Bibliográficas.

SUMMARY: Introduction; 1 . The State of Matter in the Jurisprudence of the Supreme Court; 1.1 The Decision of the HC 71373/RS Paradigm of 10.11.1994; 1.2 The Appointment of a new Perspective of the STF; 1.3 The Manifestation of the Supreme Court Expressed the Need for Renewed discussion of the Matter: The indispensability of coercive conduct the investigation for the DNA testing in the name of fundamental right to be genetic identity; 2 . The Current Paradigm of Legal Theory: The need for new thinking about the coercive conduct alleged father; 3. The Case of Coercive Conduct of the Investigated DNA Testing A hard case; 4. The Standards and Infra Repetition Jurisprudential not Self; 5. The Fundamental Right to Genetic Identity in Brazilian Law; 6. Human Dignity and Fundamental Right to Genetic Identity of the Child versus Freedom, Physical Integrity and Interest of the supposed father did not produce evidence against himself; Conclusion; References.

\section{INTRODUÇÃO}

A interpretação e a aplicação dos direitos fundamentais têm ocupado grande espaço nos estudos jurídicos acadêmicos e nas discussões práticas no âmbito dos processos judiciais, em especial nos chamados casos difíceis, em que o método positivista do silogismo mostra-se insuficiente. É nesse contexto que surge a controvérsia entre o direito fundamental à identidade genética do ser, como decorrência da dignidade da pessoa humana, e o interesse do suposto pai, em uma ação investigatória de paternidade, de não ser conduzido coercitivamente para realização de exame de DNA.

Embora o Supremo Tribunal Federal (STF) tenha decidido, em 1994, no Habeas Corpus 71373/RS, que o investigado não pode ser conduzido coercitivamente para realização de exame de DNA, devendo o investigante 
contentar-se com a presunção ficta de paternidade, tal entendimento, embora aceito no âmbito dos tribunais pátrios, nunca deixou de ser criticado pela doutrina e, recentemente, voltou ao centro das discussões no âmbito da Corte Constitucional brasileira. Com efeito, em 15.12.2011, no julgamento do RE 363889/DF, os Ministros do STF voltaram a discutir o conteúdo do direito fundamental à identidade genética, concluindo que deveria prevalecer sobre a garantia fundamental da coisa julgada. Mas, muito além disso, três Ministros da Suprema Corte afirmaram expressamente que a questão da (im)possibilidade de condução coercitiva do investigado deveria ser novamente debatida no âmbito do STF, indicando uma possível mudança de entendimento. Em razão disso, se a crítica situava-se apenas no âmbito doutrinário, a partir dessa decisão o debate reacende-se também na seara judicial, ganhando novamente centralidade.

A par de tudo isso, o presente trabalho terá como objetivo precípuo desenvolver o conteúdo do direito fundamental à identidade genética e verificar se, diante do paradigma atual do direito, os fundamentos da decisão do STF no HC 71373/RS, de 1994, ainda se sustentam ou, ao contrário, se tal decisão merece ser revista.

Para atingir esses escopos, o artigo abordará, inicialmente, a decisão paradigma do HC 71373/RS, bem como outras decisões da Suprema Corte sobre o direito fundamental à identidade genética, quando em confronto com outros direitos fundamentais. Após, trata-se do novo paradigma da teoria do direito, que indicará a necessidade de uma maior reflexão acerca da condução coercitiva do suposto pai.

Na sequência, trata-se da condução coercitiva do investigado ao exame de DNA como um caso difícil, que deve ser interpretado de acordo com a nova hermenêutica constitucional. Posteriormente, faz-se uma análise reflexiva sobre as normas infraconstitucionais e a repetição jurisprudencial não autoconsciente, delineando-se também o direito fundamental à identidade genética no ordenamento jurídico brasileiro. Por fim, são abordados construtivamente a dignidade da pessoa humana e o direito fundamental à identidade genética da criança, de um lado, e, de outro, a liberdade, a integridade física e o interesse do suposto pai de não produzir prova contra si mesmo, o que permitirá - seja pelo método da interpretação construtiva, seja pela ponderação - a conclusão acerca da possibilidade da condução coercitiva ao exame de DNA.

Para o desenvolvimento do trabalho, são adotados os métodos de abordagem dialético e hipotético-dedutivo, bem como os métodos de procedimento histórico, comparativo e estruturalista.

\section{O ESTADO DA QUESTÃO NA JURISPRUDÊNCIA DO STF}

Inicialmente, é preciso analisar a evolução da jurisprudência do Supremo Tribunal Federal no tocante à delimitação do conteúdo do direito fundamental à identidade genética, sobretudo em relação ao seu confronto com outros direitos e garantias fundamentais. 


\subsection{A Decisão Paradigma do HC 71373/RS, de 10.11.1994}

O Supremo Tribunal Federal, no julgamento do Habeas Corpus 71373/RS, de 10.11.1994, em decisão majoritária (6 votos a 4), reconheceu a inadmissibilidade da condução coercitiva do investigado (suposto pai) para a realização de exame de DNA, o que serviu de paradigma para o desenvolvimento legislativo e jurisprudencial que se seguiu sobre a institucionalização dessa matéria. Abaixo, transcreve-se a ementa da referida decisão:

INVESTIGAÇÃO DE PATERNIDADE. EXAME DNA. CONDUÇÃO DO RÉU "DEBAIXO DE VARA". Discrepa, a mais não poder, de garantias constitucionais implícitas e explícitas - preservação da dignidade humana, da intimidade, da intangibilidade do corpo humano, do império da lei e da inexecução específica e direta de obrigação de fazer - provimento judicial que, em ação civil de investigação de paternidade, implique determinação no sentido de o réu ser conduzido ao laboratório, "debaixo de vara", para coleta do material indispensável à feitura do exame DNA. A recusa resolve-se no plano jurídico-instrumental, consideradas a dogmática, a doutrina e a jurisprudência, no que voltadas ao deslinde das questões ligadas à prova dos fatos. (STF, HC 71373/RS, Relator Min. Francisco Rezek, Relator p/ Acórdão Min. Marco Aurélio, Tribunal Pleno, julgado em 10.11.1994, DJ 22.11.1996)

No entanto, tal decisão, além de ter sido muito controvertida entre os Ministros, não encontrou grande adesão dos juristas ou da sociedade, embora repetida irrefletidamente pela jurisprudência.

Os Ministros Francisco Rezek, IImar Galvão, Carlos Veloso e Sepúlveda Pertence votaram por manter o acórdão do Tribunal de Justiça do Rio Grande do Sul que, à época, havia determinado a condução coercitiva para exame de DNA. Em divergência, os Ministros Marco Aurélio, Celso de Mello, Sidney Sanches, Néri da Silveira, Moreira Alves e Octavio Gallotti adotaram a tese de que não seria possível a condução coercitiva para a realização do exame de DNA, entendimento que, na época, foi vencedor, não obstante a grande divergência.

No entanto, como a decisão de 1994 foi construída argumentativamente considerando os pressupostos fáticos e o direito existente à época, é preciso verificar se, no momento presente, com o atual desenvolvimento da filosofia e da teoria do direito, das ciências biológicas e da sociedade pós-moderna, tal entendimento ainda se sustentaria, ou se, diante do contexto atual, os pressupostos da referida decisão não são mais válidos, merecendo revisão.

Antes de adentrar no paradigma atual, que deve motivar uma revisão da referida decisão, é imperioso observar que, mesmo à sua época (1994), os argumentos a favor da obrigatoriedade de realização de exame de DNA já pareciam ser mais substanciosos.

O parecer do Ministério Público Federal, apresentado pelo Ex-ProcuradorGeral da República, Cláudio Fonteles - na época Subprocurador-Geral -, 
foi pela possibilidade de condução coercitiva do investigado para realização do exame de DNA. No parecer, consta que não pode ser aplicada a lógica processual penal da não autoincriminação. Fonteles ressaltou que, diante do conflito do filho investigante e do suposto pai investigado, ninguém pode furtar-se à definição desse vínculo. ${ }^{2}$

O Ministro Francisco Rezek, relator do referido processo, asseverou que deve se fazer uma ponderação entre os direitos fundamentais envolvidos para se verificar qual deve prevalecer, se "o da criança à sua real (e não apenas presumida) identidade, ou o do indigitado pai à sua intangibilidade física". Segundo Francisco Rezek, não se poderia enfrentar o caso centrando-se as atenções no investigado, como se a lógica fosse penal. Além disso, também afirmou que não se pode ter apenas uma visão individuocêntrica, preocupada apenas com as prerrogativas do investigado, enquanto se está diante do "direito elementar que tem a pessoa de conhecer a sua origem genética". De outro lado, também concluiu que a recusa do suposto pai em fazer o exame de DNA induz à presunção de paternidade, facilitando a decisão da demanda, mas resolve de modo insatisfatório o direito à identidade genética do investigante. ${ }^{3}$ Nessa linha de raciocínio, o Ministro Rezek concluiu que o direito ao próprio corpo "não é absoluto ou ilimitado" e que "o princípio da intangibilidade do corpo humano, que protege um interesse privado, deve dar lugar ao direito à identidade, que salvaguarda, em última análise, um interesse também público". ${ }^{4}$

Ao fazer uma ponderação entre o direito à integridade física do suposto pai e o direito à identidade biológica da criança, o Ministro Francisco Rezek afirmou que "O sacrifício imposto à integridade física do paciente é risível quando confrontado com o interesse do investigante, bem assim com a certeza de que a prova pericial pode proporcionar à decisão do magistrado" ${ }^{5}$.

No mesmo julgamento, o Ministro Ilmar Galvão, acompanhando o entendimento do Ministro Francisco Rezek (voto vencido), ressaltou a importância desse direito, afirmando que "Trata de interesse que ultrapassa os limites estritos da patrimonialidade, possuindo nítida conotação de ordem pública, aspecto suficiente para suplantar, em favor do pretenso filho, o egoístico direito à recusa, fundado na incolumidade física, no caso, afetada em proporção ridícula." ${ }^{\circ}$

A esse respeito, o Ministro Carlos Velloso acrescentou que o direito do filho de conhecer o seu pai biológico é um direito à dignidade pessoal. Nessa linha, salientou que a presunção legal gerada pela confissão ficta - em razão da recusa do suposto pai de fazer o exame - pode ter importância para

\footnotetext{
${ }^{2}$ BRASIL. Supremo Tribunal Federal. HC 71373/RS, Relator: Min. Francisco Rezek, Relator p/ Acórdão: Min. Marco Aurélio, Tribunal Pleno, Julgado em 10.11.1994, DJ 22.11.1996, p. 410.

${ }^{3}$ BRASIL. Supremo Tribunal Federal. HC 71373/RS, Relator: Min. Francisco Rezek, Relator p/ Acórdão: Min. Marco Aurélio, Tribunal Pleno, Julgado em 10.11.1994, DJ 22.11.1996. p. 410.

${ }^{4}$ Ibidem. p. 412.

${ }^{5}$ Ibidem. p. 423.

${ }^{6}$ Ibidem. p. 415.
} 
satisfação de meros interesses patrimoniais, mas "não resolve, não é bastante suficiente quando estamos diante de interesses morais, como o direito à dignidade que a Constituição assegura à criança e ao adolescente." O Ministro Velloso também fundamentou que "não há no mundo interesse moral maior que este: o do filho conhecer ou saber quem é o seu pai biológico" e que o "exame, no caso, é obrigatório, deve ser realizado".

No mesmo sentido, o Ministro Sepúlveda Pertence, ao dar prevalência ao direito à identidade genética, ressaltou o grave prejuízo à dignidade da criança se não fosse possível obrigar o suposto pai a fazê-lo e, de outro lado, "o risível sacrifício imposto à inviolabilidade corporal à eminência dos interesses constitucionalmente tutelados à investigação da própria paternidade". 8

No entanto, o Ministro Marco Aurélio iniciou a divergência e votou pela impossibilidade de condução coercitiva do investigado, em nome da integridade física do indivíduo, o que se tornou a tese vencedora. Em seu voto, fundamentou que "É irrecusável o direito do Paciente de não ser conduzido, mediante coerção física, ao laboratório. É irrecusável o direito do Paciente de não permitir que se lhe retire, das próprias veias, porção de sangue, por menor que seja, para a realização do exame."

No entanto, tal decisão do STF, de 1994, embora tenha sido amplamente observada pelos tribunais pátrios, não foi imune às críticas da doutrina e de grande parte dos juristas.

Assim, pretende-se trazer novamente à discussão a questão da condução coercitiva do investigado para realização de teste de DNA, sem, obviamente, desconsiderar a decisão do STF, no HC 71373/RS. Pelo contrário, tem-se como ponto de partida a referida decisão, mas, como adiante se demonstrará, o direito e os pressupostos fáticos e científicos atuais são outros, o que deve ser levado em consideração.

A esse respeito, lembre-se que, na contemporaneidade, o direito é compreendido como fato, valor e norma, conforme a Teoria Tridimensionalista de Miguel Reale, razão pela qual o direito somente pode ser conhecido quando houver a sua aplicação aos fatos, fazendo-se a necessária valoração. ${ }^{9} \mathrm{O}$ mesmo autor ensina que "O Direito é, por conseguinte, um fato ou fenômeno social; não existe senão na sociedade e não pode ser concebido fora dela. Uma das características da realidade jurídica é, como se vê, a sua socialidade, a sua qualidade de ser social.".10

Assim, diante da vicissitude natural no contexto social, é o caso de se reexaminar a decisão do STF e verificar se, de acordo com a sociedade pós-moderna e com o direito contemporâneo, os seus pressupostos ainda

\footnotetext{
${ }^{7}$ Ibidem. p. 422-423.

${ }^{8}$ BRASIL. Supremo Tribunal Federal. HC 71373/RS, Relator: Min. Francisco Rezek, Relator p/ Acórdão: Min. Marco Aurélio, Tribunal Pleno, Julgado em 10.11.1994, DJ 22.11.1996. p. 424.

${ }^{9}$ REALE, Miguel. Filosofia do Direito. 5. ed., São Paulo: Saraiva, 2003. p. 511.

${ }^{10}$ REALE, Miguel. Lições Preliminares de Direito. 27. ed., São Paulo: Saraiva, 2002. p. 2.
} 
se mantêm ou se ela deve ser revisada. No entanto, no atual paradigma de direito, não se pode admitir que seja irrefletidamente repetida uma decisão proferida há 18 (dezoito) anos, que, embora à época pudesse ter bons argumentos e pressupostos, atualmente talvez não se sustentem mais.

\subsection{A Indicação de uma nova Perspectiva do STF}

A par da decisão proferida no HC 71373/RS, de 1994, o Supremo Tribunal Federal, no julgamento da Questão de Ordem na Reclamação 2040, de 21.02.2002 (o conhecido caso Glória Trevi), já dava indícios de que a decisão anterior tivesse de ser revisada. Neste processo, a Corte Constitucional brasileira admitiu como meio de prova um exame de DNA realizado com a utilização da placenta da mãe (Glória Trevi), após o nascimento do filho, mesmo sem o consentimento dela. Nesse julgado, o STF considerou que a moralidade administrativa, a persecução penal pública, o direito à honra e à imagem de policiais federais acusados de estupro da extraditanda, nas dependências da Polícia Federal, e o direito à imagem da própria instituição, deveriam prevalecer em detrimento do direito da reclamante à intimidade e do direito a preservar a identidade do pai de seu filho. ${ }^{11}$

De outro lado, no julgamento do RE 248869, em 07.08.2003, a Segunda Turma do STF, ao analisar a legitimidade do Ministério Público para propor a ação investigatória de paternidade, entendeu que, ponderando-se o direito constitucional da necessária intervenção do advogado (art. 133 da Constituição Federal) e o direito à identidade biológica, este deveria prevalecer. Na ementa da referida decisão, ficou consignado expressamente que "O direito ao nome insere-se no conceito de dignidade da pessoa humana e traduz a sua identidade, a origem de sua ancestralidade, o reconhecimento da família, razão pela qual o estado de filiação é direito indisponível". Também foi salientado que "O direito à intimidade não pode consagrar a irresponsabilidade paterna, de forma a inviabilizar a imposição ao pai biológico dos deveres resultantes de uma conduta volitiva e passível de gerar vínculos familiares."12

Após esses dois julgados, o STF já apontava para uma de entendimento, conferindo uma maior proteção ao direito fundamental à identidade biológica.

1.3. A Manifestação Expressa do STF sobre a Necessidade de Rediscussão da Matéria: A imprescindibilidade de condução coercitiva do investigado para realização do exame de DNA em nome do direito fundamental à identidade genética do ser

O Supremo Tribunal Federal, na sua composição plenária, durante o julgamento do RE 363889/DF, em 15.12.2011, indicou a necessidade de reanálise da decisão proferida no HC 71373/RS, de 1994, que impedia a condução coercitiva do investigado para realização de exame de DNA.

\footnotetext{
${ }^{11}$ BRASIL. Supremo Tribunal Federal. Rcl 2040 QO. Relator: Min. Néri da Silveira. Tribunal Pleno, Julgado em 21.02.2002, DJ 27.06.2003.

12 BRASIL, Supremo Tribunal Federal. RE 248869. Relator: Min. Maurício Corrêa. Segunda Turma, Julgado em 07.08.2003, DJ 12.03.2004.
} 
Nessa nova decisão, o direito fundamental à identidade genética foi confrontado com a garantia fundamental da coisa julgada e a segurança jurídica, numa ação investigatória de paternidade que foi ajuizada a despeito da coisa julgada que havia se operado em anterior ação investigatória de paternidade, na qual não foi realizado exame de DNA. Nesse caso, o Pleno do STF entendeu que o direito fundamental à identidade genética, como manifestação da dignidade da pessoa humana, deveria prevalecer. Com essa motivação, a Corte Constitucional entendeu por relativizar a coisa julgada havida num processo no qual não foi produzido exame de DNA - porque a pessoa não teria conseguido custear as despesas do exame - e determinou 0 prosseguimento de um outro processo, posteriormente ajuizado, no qual se postulava a realização do exame.

O STF deixou claro que "Não devem ser impostos óbices de natureza processual ao exercício do direito fundamental à busca da identidade genética, como natural emanação do direito de personalidade de um ser, de forma a tornar-se igualmente efetivo o direito à igualdade entre os filhos, inclusive de qualificações, bem assim o princípio da paternidade responsável". Observe-se a íntegra da ementa:

RECURSO EXTRAORDINÁRIO. (...) REPERCUSSÃO GERAL RECONHECIDA. AÇÃO DE INVESTIGAÇÃO DE PATERNIDADE DECLARADA EXTINTA, COM FUNDAMENTO EM COISA JULGADA, EM RAZÃO DA EXISTÊNCIA DE ANTERIOR DEMANDA EM QUE NÃO FOI POSSÍVEL A REALIZAÇÃO DE EXAME DE DNA, POR SER O AUTOR BENEFICÁRIO DA JUSTIÇA GRATUITA E POR NÃO TER O ESTADO PROVIDENCIADO A SUA REALIZAÇÃO. REPROPOSITURA DA AÇÃO. POSSIBILIDADE, EM RESPEITO À PREVALÊNCIA DO DIREITO FUNDAMENTAL À BUSCA DA IDENTIDADE GENÉTICA DO SER, COMO EMANAÇÃO DE SEU DIREITO DE PERSONALIDADE. (...) 2. Deve ser relativizada a coisa julgada estabelecida em ações de investigação de paternidade em que não foi possível determinar-se a efetiva existência de vínculo genético a unir as partes, em decorrência da não realização do exame de DNA, meio de prova que pode fornecer segurança quase absoluta quanto à existência de tal vínculo. 3. Não devem ser impostos óbices de natureza processual ao exercício do direito fundamental à busca da identidade genética, como natural emanação do direito de personalidade de um ser, de forma a tornar-se igualmente efetivo o direito à igualdade entre os filhos, inclusive de qualificações, bem assim o princípio da paternidade responsável. 4. Hipótese em que não há disputa de paternidade de cunho biológico, em confronto com outra, de cunho afetivo. Busca-se o reconhecimento de paternidade com relação a pessoa identificada. 5. Recursos extraordinários conhecidos e providos. $^{13}$

\footnotetext{
${ }^{13}$ BRASIL, Supremo Tribunal Federal. RE 363889. Relator: Min. Dias Toffoli. Tribunal Pleno, Julgado em 02.06.2011. Acórdão Eletrônico Repercussão Geral - Mérito DJe-238, divulg. 15.12.2011, public. 16.12.2011.
} 
Essa decisão plenária foi tomada por maioria de votos, restando vencidos os Ministros Marco Aurélio e Cezar Peluso, e estando ausentes o Ministro Celso de Mello e a Ministra Ellen Gracie.

No referido processo, o juiz de primeira instância havia rejeitado a preliminar de coisa julgada, mas o Tribunal de Justiça do Distrito Federal e dos Territórios deu provimento ao agravo de instrumento e acolheu a preliminar, extinguindo o processo sem resolução de mérito com fundamento na coisa julgada. O Ministério Público e o autor recorreram do acórdão do TJDFT, e o STF proveu o recurso extraordinário para determinar o prosseguimento da ação investigatória de paternidade, sob o fundamento de que prevalece o direito fundamental à identidade biológica do ser em detrimento da garantia fundamental da coisa julgada.

No entanto, apesar de o processo não ter por objeto a questão da condução coercitiva do investigado para realização de exame de DNA, foram trazidos diversos argumentos que dão a entender que, se novamente fosse posta à apreciação da Corte Constitucional, a questão poderia ter outra solução, em nome do direito fundamental à identidade biológica.

No voto do Relator, Ministro Antônio Dias Toffoli, ficou expresso que essa matéria merece trilhar um novo caminho, a fim de que se reconheça a verdadeira identidade biológica. In verbis:

"Creio que se faz chegado o momento, Senhores Ministros, no qual é necessário continuar a enveredar por esse caminho, que de há muito vem sendo trilhado por esta Suprema Corte, no sentido de permitir, em matéria de direito de filiação, que a verdade sobre a origem biológica seja investigada e que uma resposta calcada em critérios técnicos de quase absoluta veracidade seja proferida pela Justiça. ${ }^{14}$

O Ministro Toffoli deixou claro o seu posicionamento a favor do direito à identidade genética, em detrimento da verdade fictícia estabelecida sem a realização do exame de DNA, afirmando expressamente que:

(...) mostra-se de todo conveniente permitir-se a realização do exame de DNA, para que, com absoluta segurança, venha a ser proferida decisão judicial acerca da origem biológica do autor da demanda $(. . .)^{15}$

Da mesma forma que não se pode mais tolerar a prevalência, em relações familiares envolvendo o vínculo paterno-filial, do fictício critério da verdade legal, calcado na absoluta presunção que decorria do vetusto brocardo "pater is est", tampouco compactua o sistema vigente entre nós com a negativa de resposta a demandas acerca da origem biológica do ser humano, tendo por fundamento a ausência de realização de prova técnica que permita a prolação de um juízo de certeza sobre a existência

\footnotetext{
14 Ibidem. p. 43-44.

15 Ibidem. p. 21.
} 
de uma tal relação, objeto esse que se constitui no cerne da controvérsia em disputa na presente demanda.

O que se está a fazer, neste caso, é dar ênfase ao direito fundamental à informação genética, que já foi examinado pelo Tribunal Constitucional Federal alemão, no famoso caso da "informação sobre a paternidade" (...). Trata-se de pura e simplesmente reconhecer que houve evolução nos meios de prova e que a defesa do acesso à "informação sobre a paternidade" deve ser protegida porque se insere no conceito de direito da personalidade. ${ }^{16}$

Nesse mesmo julgamento (RE 363889, de 15.12.2011), o Ministro Ricardo Lewandowski, em seu voto, também conferiu especial relevo ao direito fundamental à identidade genética, salientando que "Há um segundo aspecto, muito bem ressaltado pelo juízo de primeiro grau, que disse estarmos diante de uma ação de estado, em que deve prevalecer a verdade real, e não a verdade ficta ou processual". ${ }^{17}$

Ainda mais enfático na defesa do direito à identidade genética foi o voto do Ministro Carlos Ayres Britto, ao afirmar que "o fato é que esse direito de reconstituir a história, a biografia do indivíduo, a partir da identidade do pai ou da mãe, ou de ambos, parece-me de fundamentalidade autoevidente."18 O Ministro Britto ainda afirma que "a Constituição, aqui, faz, ainda que por implicitude, uma ponderação de valores em favor desse tipo de direito elementaríssimo: a busca da própria identidade biológico-familiar, ou genealógica", sendo que a "falta de conhecimento desse elo torna incompleta a biografia do indivíduo. Vale dizer, a personalidade não se perfaz, no sentido constitucionalmente biográfico". ${ }^{19}$

Se até então estava implícito que os Ministros poderiam revisar o entendimento da (im)possiblidade de condução coercitiva para realização de exame de DNA, a partir dos debates abaixo transcritos entre os Ministros do STF não resta mais qualquer dúvida a esse respeito.

Com efeito, o Ministro Gilmar Mendes levantou a questão da decisão do HC 71373/RS, de 1994, que impediu a condução coercitiva para realização de exame de DNA, e mencionou que ela talvez tivesse de ser revista, com o que foi seguido pelos Ministros Carlos Ayres Britto e Antônio Dias Toffoli. Observe-se o seguinte trecho do acórdão, em que consta o referido debate ${ }^{20}$ :

\footnotetext{
16 BRASIL, Supremo Tribunal Federal. RE 363889. Relator: Min. Dias Toffoli. Tribunal Pleno, Julgado em 02.06.2011, Acórdão Eletrônico Repercussão Geral - Mérito DJe-238, divulg. 15.12.2011, public. 16.12.2011. p. 46.

17 Ibidem. p. 120.

18 Ibidem. p. 127.

19 Ibidem. p. 129.

20 BRASIL, Supremo Tribunal Federal. RE 363889. Relator: Min. Dias Toffoli. Tribunal Pleno, Julgado em 02.06.2011. Acórdão Eletrônico Repercussão Geral - Mérito DJe-238, divulg. 15.12.2011, public. 16.12.2011. p. 132-134.
} 
O SENHOR MINISTRO GILMAR MENDES - Presidente, a mim me parece que, do ponto de vista substancial, do ponto de vista substantivo, nós estamos a falar realmente num direito à própria identidade, tanto é que, nos comentários e críticas que se fazem à nossa decisão, à jurisprudência majoritária e, também, à jurisprudência de Direito comparado, que, eventualmente, permite a negativa da prestação da prova, diz-se que aqui talvez teria que se fazer um outro balanceamento. Não se trata sequer de resolver o problema com base apenas na presunção. Há um quid de psicológico na busca dessa identidade, que vai para muito além da questão patrimonial. Não se trata apenas de fazer um registro no cartório, mas de fato saber quem é o seu pai, de onde vem. Não se trata apenas de resolver a questão do ponto de vista civil, cartorial, para todos os efeitos, mas há um liame psicológico que diz respeito à própria identidade da pessoa; o seu modo de ser no mundo. Isso é extremamente importante. Eu, inclusive, em outro momento, se essa questão se colocar, vou me permitir pelo menos pensar criticamente em relação a esse balanceamento.

O SENHOR MINISTRO AYRES BRITTO - Se Vossa Excelência me permite? Aqui o aspecto material, não do ponto de vista de fato, mas do ponto de vista jurídico, é um minus, porque o que se está buscando é o elo identitário do ser humano. Esse elo perdido, que precisa ser resgatado.

O SENHOR MINISTRO GILMAR MENDES - É claro que a solução do STJ é, por todos os títulos, louvável, porque ela, diante dos impasses verificados, do ponto de vista jurídico e jurídico/processual, encaminha uma solução. Mas é preciso, inclusive, que nós saibamos que isso é um provisorum no contexto dessa ânsia, angústia por ter uma definição, quer dizer, a certeza que a ciência permite. É disso que se fala.

O SENHOR MINISTRO DIAS TOFFOLI (RELATOR): No meu voto, Ministro Gilmar Mendes, inclusive eu destaquei muito esse aspecto relativo à evolução da legislação sob o impacto da jurisprudência do Poder Judiciário, e também desta Suprema Corte, ao longo do Século $X X$, no sentido de se abolir as ficções legais. E ainda temos algumas ficções que são, hoje, construídas por sentença judicial.

O SENHOR MINISTRO AYRES BRITTO - Pela verdade real.

O SENHOR MINISTRO DIAS TOFFOLI (RELATOR): Substitui a ficção legal que havia, tão prejudicial, por uma ficção de sentença. E não é disso que se trata. Trata-se da busca da verdade.

A partir desse momento, os Ministros do STF voltaram a se circunscrever à questão da coisa julgada versus direito à identidade biológica, que era 0 objeto da ação que estava sendo julgada.

Embora o STF tenha adotado, em diversas oportunidades, uma postura perfeccionista, o referido acórdão foi minimalista, vale dizer, se circunscreveu a dizer que a coisa julgada deveria ser relativizada em nome do direito fundamental à identidade biológica, mas o Pleno não chegou a manifestar o seu entendimento sobre a (im)possibilidade de condução coercitiva para realização de exame de DNA. 
No entanto, os Ministros Gilmar Mendes, Carlos Ayres Brito e Antônio Dias Toffoli deixaram transparecer, obter dictum, que o direito à identidade biológica do filho (investigante) deveria prevalecer sobre o direito do suposto pai (investigado) a não ser conduzido coercitivamente, ou ao menos que deveria haver uma nova reflexão sobre isso, pois não se poderia admitir que uma ação investigatória de paternidade fosse decidida com base em mera ficção jurídica ou presunção.

De outro lado, o Pleno do STF reafirmou o direito à identidade genética como um direito fundamental decorrente da dignidade da pessoa humana, sendo um supra direito, e também demonstrou que pode ser desconstituída uma sentença produzida num processo em que não foi realizado exame de DNA, mesmo que transitada em julgado.

Nesse sentido, depois desse julgado (RE 363889, de 2011), em que foi relativizada a garantia fundamental da coisa julgada em nome do direito à identidade biológica, e em que três Ministros deixaram transparecer a necessidade de revisão do paradigma anterior a respeito da obrigatoriedade do teste biológico de paternidade, parece intuitivo que, caso a matéria seja novamente discutida, o STF entenderá que o direito do investigado de não fornecer um fio de cabelo ou saliva para o teste de DNA é um valor inferior ao direito fundamental à identidade biológica. Aliás, todos esses novos julgamentos do STF indicam que haverá uma mudança de entendimento acerca da (im)possibilidade de condução coercitiva do investigado para exame de DNA.

Assim, a partir desse panorama da jurisprudência do Supremo Tribunal Federal, que mostra certa indefinição, passa-se a analisar, no presente estudo, se é possível a condução coercitiva do investigado para realização de exame de DNA, em nome do direito à identidade genética do ser humano, ou, ao contrário, se tal constrição da liberdade individual implicaria a violação de direitos fundamentais superiores, o que impediria a condução coercitiva.

Para tanto, é imperioso inicialmente analisar o novo paradigma do direito no contexto da sociedade contemporânea, a fim de verificar se os elementos que nortearam a decisão do HC 71373/RS, proferida há 18 anos atrás, ainda se sustentam.

\section{O PARADIGMA ATUAL DA TEORIA DO DIREITO: A NECESSIDADE DE UMA NOVA REFLEXÃO ACERCA DA CONDUÇÃO COERCITIVA DO SUPOSTO PAI}

A era da pós-modernidade ${ }^{21}$ emerge como um construto, sobretudo social, político, científico, histórico e filosófico, com ideias reacionárias às concepções e às ideologias associadas à modernidade, sendo menos categorizantes, menos formalistas, mais abertas, propondo novos valores e uma nova compreensão da precariedade de si mesma.

${ }^{21}$ O termo pós-modernidade não é de aceitação geral. Muitos preferem utilizar o termo contemporaneidade para designar o momento atual. 
Do ponto de vista filosófico, reconhecem-se as pretensões abusivas da racionalidade humana, buscando-se a superação do mito da sociedade moderna, que seria capaz de revelar verdades eternas, imutáveis, a-históricas, bem como reconhecem-se as consequências desastrosas da crença nesse mito. ${ }^{22}$ Concebe-se que a verdade não é um dado, não pode existir independente da racionalidade humana. A verdade é diuturnamente construída e reconstruída pela mente humana através da linguagem. ${ }^{23}$

O pós-positivismo ${ }^{24}$ surge nesse contexto da pós-modernidade. O direito da pós-modernidade passa a ser constituído e refletido com forte influência da filosofia política e moral.

Os autores do pós-positivismo não dão nenhuma resposta fácil ou reducionista para esses casos difíceis, tampouco têm a pretensão de criar um processo mecânico de aplicação da lei. Pelo contrário, consideram que juízes e juristas sensatos frequentemente divergirão sobre a norma a ser aplicada no caso concreto. ${ }^{25}$

Nesse sentido, a correção dos juízos normativos não pode ser explicada com base em uma teoria da verdade, pois os direitos são construtos sociais que não admitem essa concepção do verdadeiro e do falso. A correção do juízo normativo exige aceitabilidade racional apoiada em argumentos. A validade de um juízo somente pode ser definida através de condições de validade (argumento válido ou inválido), e isso somente é possível através do discurso, vale dizer, pelo caminho da fundamentação que se desenvolva argumentativamente. ${ }^{26}$

Com base no princípio do discurso, na autonomia pública e privada e no agir comunicativo, o povo assume a construção do direito pelo próprio

22 CARVAlho NETTO, Menelick de; SCOTTI, Guilherme. Os Direitos Fundamentais e a (in)certeza do Direito: A produtividade das tensões principiológicas e a superação do sistema de regras. Belo Horizonte: Fórum, 2011. p. 25.

${ }^{23}$ RORTY, Richard. Contingência, Ironia e Solidariedade. (trad. Vera Ribeiro). São Paulo: Martins Fontes, 2007. p. 28-30.

${ }^{24}$ Albert Calsamiglia, apontado como o primeiro autor a utilizar essa designação, denomina "postpositivistas a las teorías contemporáneas que ponen el acento en los problemas de la indeterminación del derecho y las relaciones entre el derecho, la moral y la política". Segundo o autor, "El postpositivismo cambia la agenda de problemas porque presta especial atención a la indeterminación del derecho. Se desplaza el centro de atención de los casos claros o fáciles a Ios casos difíciles." (CALSAMIGLIA, Albert. Postpositivismo. Doxa, 21, nº 1, p. 209-220, 1998. p. 209-211). No entanto, outros autores, como Manoel Gonçalves Ferreira Filho, entendem que o termo é inapropriado (Notas sobre o direito constitucional pós-moderno, em partilhar sobre certo neoconstitucionalismo à brasileira. Revista de Direito Administrativo, Rio de Janeiro, v. 250, p. 151-167, jan./abr. 2009). De qualquer forma, não se pode negar que existe um novo paradigma da teoria do direito na atualidade.

${ }^{25}$ DWORKIN, Ronald. Levando os Direitos a Sério. (trad. Nelson Boeira). 3. ed., São Paulo: Martins Fontes, 2010. p. 127-128.

${ }^{26}$ HABERMAS, Jürgen. Direito e Democracia: Entre faticidade e validade. v. 1. (trad. Flávio Beno Siebeneichler). Rio de Janeiro: Tempo Brasileiro, 2010. p. 281-282. 
exercício da comunicação, quando os cidadãos se reconhecem livres e iguais. Os cidadãos são, ao mesmo tempo, criadores e destinatários da ordem jurídica. ${ }^{27}$

Assim, a estrutura da argumentação não pode ser hermética, voltada apenas para um número reduzido de especialistas; ao contrário, a argumentação deve servir para as interações entre os interlocutores e com o cotidiano.

Portanto, o desenvolvimento do direito, com a reaproximação da filosofia moral e política, culmina tornar totalmente ultrapassados os ideais formalistas e mecanicistas de interpretação e aplicação do direito na forma preconizada pelo positivismo jurídico, o qual não encontra mais espaço diante da sociedade de massas, da complexidade social, da concepção de normas construídas discursivamente e da constitucionalização dos direitos.

O direito se revela não somente através de textos escritos, mas também - e sobretudo - por discursos vivencialmente construídos e reconstruídos, nos quais é considerada fundamentalmente a tensão existente entre o valor justiça, a razoabilidade, os resultados hermenêuticos satisfatórios do ponto de vista prático, a abertura do sistema, a clareza metodológica, a segurança jurídica, a previsibilidade, a transparência, a formação de unidade, a harmonização e a força normativa da Constituição, o direito ao respeito e à igual consideração, a proteção efetiva da liberdade e da igualdade social, a ordem pública voltada para o bem comum e a defesa intransigente dos direitos fundamentais.

Com base nesse ambiente filosófico, teorético e pragmático é que se deve analisar qual direito deve prevalecer: se o interesse do investigado de não ser submetido coercitivamente a exame de DNA ou o direito à identidade biológica da criança.

Assim, não se pode apenas dizer que a condução coercitiva do investigado está vedada por ausência de previsão legal. No paradigma atual, o direito é entendido como integridade. Se não existe uma regra legal sobre a hipótese fática, o intérprete e o juiz devem buscar uma solução com base nos princípios, nas outras normas, no sistema jurídico como um todo.

Além disso, nesse novo contexto, também não se pode simplesmente admitir que se negue à pessoa humana o direito de conhecer o seu verdadeiro pai, sob o fundamento metafísico de que existe um direito à integridade física que vedaria a obrigação de fornecer um fio de cabelo, saliva ou uma ínfima quantidade de sangue. O direito atual não pode se prender nos seus próprios dogmas, quando criados no vazio e sem o real amparo de um valor fundamental. Pelo contrário, devem-se examinar quais são os valores mais caros à sociedade e, amparado nisso e nas normas constitucionais, decidir, com justificação no sistema jurídico e no mundo real, se deve prevalecer, no caso concreto, o direito à integridade física do investigado ou a identidade biológica da criança.

\footnotetext{
${ }^{27}$ HABERMAS, Jürgen. Era das Tradições. (trad. Flávio Siebeneichler). Rio de Janeiro: Tempo Brasileiro, 2003. p. 73.
} 
Portanto, a resposta para a presente questão não pode apenas ser buscada por meio da "revelação" do conteúdo das regras legais ou dos dogmas construídos com base na metafísica, sob pena de tornar o direito um instrumento de opressão. ${ }^{28}$ A solução jurídica deve ser construída racional e justificadamente dentro do mundo real e dos valores que são mais caros à sociedade.

\section{O CASO DA CONDUÇÃO COERCITIVA DO INVESTIGADO AO EXAME DE DNA - UM CASO DIFÍCIL}

Por tudo o que foi acima exposto, fica claro que a decisão do Supremo Tribunal Federal no HC 71373/RS, de 1994, foi tomada considerando circunstâncias fáticas e vivenciais diversas, quando a condução coercitiva era vista como um ato autoritário e havia um certo receio em relação a isso, diante de um processo de transição democrática que era recente e ainda prematuro.

No entanto, estando consolidada a democracia brasileira, é necessário compreender o instituto da coerção coercitiva como um instrumento excepcional de efetividade das decisões judiciais e não como o exercício arbitrário da força. O contexto político e social atual exige que se decida com base na realidade.

Além da mudança da composição de 9 (nove) membros do STF ainda permanecem os Ministros Celso de Mello e Marco Aurélio -, o que não pode ser desconsiderado, a sociedade evoluiu e exige que as decisões judiciais não sejam proferidas com base em simples dogmas técnico-jurídicos oitocentistas, que não tem mais sentido para a sociedade contemporânea.

De outro lado, não se pode ignorar que se está diante de um caso difícil, ${ }^{29}$ vale dizer, de uma hipótese fática cuja solução jurídica não está pronta e acabada no texto de lei, e em que a operação básica de subsunção é insuficiente, devendo a decisão ser construída argumentativamente pelo julgador, levando-se em consideração as normas aplicáveis, os direitos fundamentais em conflito, a realidade social, bem como as opções políticas do legislador na conformação de direitos fundamentais.

\footnotetext{
${ }^{28}$ Segundo o Professor Marcus Faro de Castro, "muitas vezes, as teorias e conceitos abstratos mostram-se completamente inadequados ou insuficientes como apoios intelectuais capazes de conduzir à superação de conflitos práticos. E insistir na utilidade ou validade prática de conceitos abstratos e amplamente abrangentes pode conduzir o jurista a adotar o expediente de escamotear a insuficiência ou inadequação das formas intelectuais empregadas para fundamentar decisões sobre problemas concretos. O direito, corre, então, o risco de tornar-se um instrumento de opressão." (CASTRO, Marcus Faro de. Formas Jurídicas e Mudança Social: Interações entre o direito, a filosofia, a política e a economia. São Paulo: Saraiva, 2012. p. 15-16)

29 "Nos casos difíceis, a identificação do efeito jurídico decorrente da incidência da norma sobre os fatos relevantes envolve uma operação simples, de mera subsunção. (...) Pode o autor de uma ação de investigação de paternidade exigir que o indigitado pai se submeta coativamente a exame de DNA? Em ambos os casos, que envolvem questões constitucionais - privacidade, liberdade de expressão, direitos da personalidade, liberdade individual - a solução para a disputa não é encontrável pré-pronta no sistema jurídico: ela precisa ser desenvolvida justificadamente pelo intérprete." (BARROSO, Luís Roberto. Constituição, Democracia de Supremacia Judicial: Direito e política no Brasil contemporâneo. Revista de Direito de Estado, Rio de Janeiro, a. 4, $\mathrm{n}^{\circ} 6$, p. 3-42, out./dez. 2009. p. 24-25)
} 
Assim, como a decisão do HC 71373 , de 1994 , teve por fundamentos pressupostos fáticos e científicos diversos do momento atual, merece ser reavaliada. No presente, abre-se novamente ao intérprete e, sobretudo, ao juiz um novo contexto fático e jurídico, onde deverá construir discursiva e vivencialmente a sua decisão, com pressupostos diversos daqueles que fundamentaram o caso paradigma julgado pelo STF.

No entanto, a interpretação e a aplicação do direito, embora não possam estar dissociadas do contexto social, também não podem estar ao largo das regras constitucionais e infraconstitucionais que regem a matéria e disciplinam os direitos que devem ser ponderados, sob pena de corromper o direito como sistema. Assim, é imperioso analisar o panorama legislativo e constitucional sobre a matéria, como ponto de partida do processo interpretativo.

\section{AS NORMAS INFRACONSTITUCIONAIS E A REPETIÇÃO JURISPRUDENCIAL NÃO AUTOCONSCIENTE}

Dentro do panorama legislativo brasileiro, observa-se que a legislação infraconstitucional não veda a condução coercitiva do suposto pai para realização de exame de DNA, tampouco a admite expressamente. No entanto, a legislação adaptou-se à decisão do Supremo Tribunal Federal no HC 71373/RS, de 1994, de modo que tentou criar outros mecanismos de coerção indireta para que o investigado fizesse o exame de DNA.

Com efeito, amparado no entendimento esposado na decisão do $\mathrm{HC}$ 71373/RS, o Código Civil de 2002 previu, no seu art. 231, que "Aquele que se nega a submeter-se a exame médico necessário não poderá aproveitar-se de sua recusa", bem como, no art. 232, que "A recusa à perícia médica ordenada pelo juiz poderá suprir a prova que se pretendia obter com o exame".

Pouco tempo depois, em 18.10.2004, o Superior Tribunal de Justiça editou a Súmula 301, segundo a qual "Em ação investigatória, a recusa do suposto pai a submeter-se ao exame de DNA induz presunção juris tantum de paternidade", para deixar claro que a presunção gerada pela recusa ao teste de DNA é relativa, pois o juiz pode, com base no conjunto probatório, julgar improcedente a ação.

Para consagrar o entendimento dessa Súmula, a Lei 12.004/09 acrescentou o art. 20-A à Lei 8.560/1992 (Lei da Ação Investigatória de Paternidade), passando a dispor o parágrafo único desse dispositivo que "A recusa do réu em se submeter ao exame de código genético - DNA gerará a presunção da paternidade, a ser apreciada em conjunto com o contexto probatório."

Assim, observa-se que, tanto os arts. 231 e 232 do Código Civil de 2002, quanto a Súmula 301 do STJ e o art. 20-A na Lei 8.560/1992 (Lei da Ação de Investigação de Paternidade), que disciplinaram que a recusa do pai a se submeter ao exame induz presunção de paternidade, foram editados em razão das contingências geradas pela decisão do STF no HC 71373, a qual, baseada no contexto social e no direito da época, impossibilitou a condução coercitiva para exame de DNA. 
Assim, fica claro que o Código Civil, a Lei 8.560/1992 e a Súmula 301 do STJ não impossibilitaram a condução coercitiva. O que ocorre é que, diante da contingência criada pela impossibilidade de condução coercitiva (coerção direta) - na decisão do HC 71373/RS -, o STJ e o legislador infraconstitucional tiveram de criar um meio de coerção indireta para que o investigado fizesse o exame de DNA, impondo-se a ele o ônus processual da presunção de paternidade.

Apesar da disciplina da coerção indireta, entretanto, a deficiência na proteção do núcleo essencial do direito fundamental à identidade genética persiste. Isso porque não se resolve o problema consistente na possibilidade fática de, mesmo com a coerção indireta, o suposto pai se recusar a fornecer material genético. Com efeito, o reconhecimento de paternidade com base numa ficção não é capaz de garantir o direito à verdadeira identidade genética, sobretudo quando as demais provas dos autos são fracas. Pelo contrário, a simples aplicação do ônus da presunção de paternidade pode violar ainda mais o direito fundamental à identidade genética, na medida em que, além de haver a possibilidade de o investigado não ser o pai, atribuindo-se à criança uma falsa paternidade, ainda se estaria impedindo que ela buscasse o seu verdadeiro pai biológico.

Assim, para que se possa verificar qual direito fundamental deve prevalecer, se o direito à identidade genética ou o direito de não ser conduzido coercitivamente, é necessário que, previamente, se delimite o conteúdo desses direitos, o que se passa a fazer no item seguinte.

\section{O DIREITO FUNDAMENTAL À IDENTIDADE GENÉTICA NO ORDENAMENTO JURÍDICO BRASILEIRO}

No direito contemporâneo, com a publicização, a constitucionalização e a repersonalização do direito privado, cada vez mais se dá importância aos direitos da personalidade.

A pessoa humana é colocada no centro de proteção do direito civil, ficando em segundo plano os aspectos meramente patrimoniais. No entanto, isso não acontece com uma visão puramente individualista, senão na perspectiva do indivíduo integrante do meio social em que vive. Assim, o indivíduo, a par de ter direitos e garantias individuais que devem ser protegidos, também deve exercê-los legitimamente, sem afrontar os direitos individuais e coletivos das outras pessoas.

No âmbito do direito de família, "A nova ordem jurídica consagrou como fundamental o direito à convivência familiar, adotando a doutrina da proteção integral. Transformou a criança em sujeito de direito. Deu prioridade à dignidade da pessoa humana, abandonando a feição patrimonialista da família." ${ }^{30}$

${ }^{30}$ DIAS, Maria Berenice. Manual do Direito das Famílias. 2. ed., Porto Alegre: Livraria do Advogado, 2005. p. 328. 
Da mesma forma, o Direito da Criança e do Adolescente, com a nova ordem constitucional, está embasado na Doutrina da Proteção Integral e nos Princípios da Absoluta Prioridade e do Melhor Interesse da Criança (The Best Interest of the Child).

Nesse novo contexto do direito constitucional, do direito de família e do direito da criança e do adolescente, o direito à identidade biológica também passa a ocupar um status singular, pois se trata de uma manifestação direta do princípio da dignidade da pessoa humana, já que diz respeito à própria identidade do ser, à sua honra subjetiva e à sua imagem, ou seja, como o próprio indivíduo se enxerga no contexto particular e na sociedade.

$\mathrm{O}$ direito à identidade genética envolve não somente o conhecimento do seu pai, mas também de toda a sua família paterna. $E$ não é só isso. Também diz respeito ao seu patronímico, sinal identificador do indivíduo na sociedade.

Além de tudo isso, a (não) descoberta do verdadeiro pai implica repercussões psicológicas inestimáveis para a criança. Toda criança, na sua criação e no seu desenvolvimento, necessita da figura paterna. É um elemento essencial à dignidade da criança o direito de descobrir o seu verdadeiro pai, aquele que a gerou, de quem herda características comportamentais, doenças hereditárias, cor da pele, dos olhos, estatura, compleição física, dentre diversos outros fatores. Todo indivíduo tem direito de conhecer aquele que tem a responsabilidade pela sua criação, com quem estará ligado, por um vínculo de sangue, até o final de seus dias.

Nada é mais desumano do que privar o ser humano do vínculo paternofilial. Segundo Giselda Hironaka, "O fato de ser a relação paterno-filial inamovível e perpétua lhe confere um traço ímpar, distinto de tudo o mais que se queira apreciar, em paralelo ou em comparação, na esfera do Direito de Família, ou no núcleo familiar". ${ }^{31}$

Aliás, o direito à identidade genética é uma manifestação da dignidade da pessoa humana, prevista no art. $1^{\circ}$, inc. III, da Constituição Federal como fundamento da República Federativa do Brasil.

Além disso, o art. 227 da Constituição Federal confere especial proteção a tal direito, ao adotar o Princípio da Prioridade Absoluta, prevendo expressamente que é dever do Estado assegurar à criança, com absoluta prioridade, o direito à dignidade, ao respeito e à convivência familiar.

Ademais, o art. 226, $\S 7^{\circ}$, da Lei Maior consagra expressamente, no âmbito do planejamento familiar, os princípios da dignidade da pessoa humana e da paternidade responsável. A esse respeito, é insofismável que não há nada mais irresponsável por parte de um suposto pai do que a recusa

\footnotetext{
${ }^{31}$ HIRONAKA, Giselda Maria Fernandes Novaes. Os Contornos Jurídicos da Responsabilidade Afetiva na Relação entre Pais e Filhos além da Obrigação Legal de Caráter Material. In: HIRONAKA, Giselda Maria Fernandes Novaes. (Coord.). A Outra Face do Poder Judiciário: Decisões inovadoras e mudanças de paradigmas. Belo Horizonte: Del Rey, 2005. p. 446-500. p. 460.
} 
a fazer o teste de DNA, afrontando diretamente o princípio da dignidade da pessoa humana.

O art. 18 da Convenção Americana de Direitos Humanos (Pacto de São José da Costa Rica), promulgada internamente pelo Decreto 678/1992, prevê que "Toda pessoa tem direito a um prenome e aos nomes de seus pais ou ao de um destes". Obviamente, quando prevê que toda pessoa tem o direito ao nome do seu pai, não se está dizendo que é o nome de qualquer pai, senão do verdadeiro pai. Assim, não há como refutar que a identidade biológica é um direito que está na categoria de direitos humanos, inerente a todo o ser humano.

A Convenção da ONU sobre Direitos da Criança, promulgada internamente pelo Decreto 99.710/1990, previu expressamente, no seu art. $3^{\circ}$, item 1, o Princípio do Melhor Interesse da Criança, atualmente consagrado no plano interno e internacional. ${ }^{32}$ No mesmo sentido, o art. 18, item 1 , dispõe que os Estados Partes da Convenção devem assegurar que ambos os pais tenham obrigações comuns ao desenvolvimento da criança e que a sua preocupação deve ser o Melhor Interesse da Criança. ${ }^{33}$

O Artigo $7^{\circ}$, item 1 , da Convenção da ONU sobre Direitos da Criança, por sua vez, não deixa qualquer dúvida sobre o direito fundamental da criança de conhecer o seu pai: "A criança será registrada imediatamente após seu nascimento e terá direito, desde o momento em que nasce, a um nome, a uma nacionalidade e, na medida do possível, a conhecer seus pais e a ser cuidada por eles".

Além disso, o direito fundamental à identidade biológica também está conformado pelo legislador no plano infraconstitucional, na regra contida no art. 27 do Estatuto da Criança e do Adolescente, que prevê que "O reconhecimento do estado de filiação é direito personalíssimo, indisponível e imprescritivel, podendo ser exercitado contra os pais ou seus herdeiros, sem qualquer restrição, observado o segredo de Justiça".

No direito comparado, também se observa que a identidade biológica é tratada como um direito fundamental. A título de exemplo, o art. 26, $\mathrm{n}^{\circ} 3$, da Constituição Portuguesa de 1976 prevê que "A lei garantirá a dignidade pessoal e a identidade genética do ser humano, nomeadamente na criação, desenvolvimento e utilização das tecnologias e na experimentação científica."

\footnotetext{
32 "Artigo $3^{\circ}$. 1. Todas as ações relativas às crianças, levadas a efeito por instituições públicas ou privadas de bem estar social, tribunais, autoridades administrativas ou órgãos legislativos, devem considerar, primordialmente, o interesse maior da criança."

33 "Art. 18. 1. Os Estados Partes envidarão os seus melhores esforços a fim de assegurar o reconhecimento do princípio de que ambos os pais têm obrigações comuns com relação à educação e ao desenvolvimento da criança. Caberá aos pais ou, quando for o caso, aos representantes legais, a responsabilidade primordial pela educação e pelo desenvolvimento da criança. Sua preocupação fundamental visará ao interesse maior da criança."
} 
Ora, diante de um direito de tal envergadura, consagrado no plano constitucional, em tratados internacionais e também na legislação infraconstitucional - além de ser também amplamente protegido no âmbito internacional -, não se pode admitir que a má-fé do suposto pai em contribuir com a Justiça para a descoberta da paternidade seja um direito oponível ao direito de conhecimento do estado de filiação, concebido pelo próprio legislador como direito indisponível e imprescritível, que pode ser exercitado contra os pais "sem qualquer restrição", frise-se (art. 27 do ECA).

Assim, com a evolução da ciência e a descoberta do exame de DNA, o direito a buscar a identidade genética passa a gozar de proteção jurídica, mas não pela verdade meramente formal, senão pela busca da verdade real, da verdadeira paternidade. A esse respeito, Maria Berenice Dias leciona que "a possibilidade de identificação da verdade genética alcançou altíssimo grau de certeza por meio do DNA, o que desencadeou uma corrida na busca da verdade real, em substituição à verdade jurídica, definida muitas vezes por presunções legais." Nesse sentido, a autora concluiu que "O direito à identidade genética é um direito da personalidade, assim como o nome e os demais elementos de identificação, devendo a informação da origem genética ser tutelada". ${ }^{34}$

Portanto, a Constituição Federal e o sistema jurídico protetivo de direito humanos não estarão sendo obedecidos se for permitido que o suposto pai se escuse ao teste de paternidade sob um argumento criado pela dogmática, que pretende obstaculizar que ele forneça material genético, impedindo-se que a criança descubra verdadeiramente a sua identidade biológica.

Os operadores do direito que atuam na seara do direito de família também percebem dia a dia o descontentamento das pessoas comuns, que não conseguem conceber como o direito pode proteger o suposto pai que, por mera recalcitrância, se recusa a produzir uma prova essencial para o estabelecimento da verdadeira paternidade, sob o simples argumento de que um fio de cabelo ou a saliva aviltaria a sua integridade física.

Observa-se que, para impedir a condução coercitiva, cria-se um dogmatismo, um óbice ao estabelecimento da verdade que é vazio de conteúdo, que é desconectado da realidade, que destoa do entendimento da doutrina especializada e que cada vez também contraria o sentimento de justiça da sociedade e da comunidade jurídica.

Deve-se salientar, ainda, os malefícios que a decisão do HC 71373/RS, de 1994, causam na atualidade, não somente ao investigado e à criança, mas também às suas próprias famílias. $O$ estabelecimento da paternidade por uma presunção legal impede que um vínculo afetivo real se desenvolva entre o investigante e o investigado, sendo que os próprios familiares deste não

34 DIAS, Maria Berenice. Manual do Direito das Famílias. 2. ed., Porto Alegre: Livraria do Advogado, 2005. p. 329. 
reconhecem verdadeiramente aquele como membro da família, diante da dúvida que sempre pairará sobre o verdadeiro vínculo de paternidade.

O direito é discursivo e vivencial, não podendo ser imposto com base num dogmatismo irrefletidamente repetido, que não atende aos reclamos do direito constitucional e da sociedade. Até o presente momento, demonstrou-se que, de acordo com uma interpretação construtiva, o direito fundamental à identidade genética deve prevalecer sobre o interesse do suposto pai de não ser conduzido coercitivamente. No item seguinte, passa-se a analisar se, com base no princípio da proporcionalidade, também é possível juridicamente a condução coercitiva do investigado para realizar o exame de DNA.

\section{DIGNIDADE DA PESSOA HUMANA E DIREITO FUNDAMENTAL À IDENTIDADE GENÉTICA DA CRIANÇA VERSUS LIBERDADE, INTEGRIDADE FÍSICA E INTERESSE DO SUPOSTO PAI DE NÃO PRODUZIR PROVA CONTRA SI MESMO}

O princípio da proporcionalidade, como método de resolução de conflitos entre direitos fundamentais, possui três elementos: a adequação (idoneidade), a necessidade e a proporcionalidade em sentido estrito. ${ }^{35}$

Com base nesses três elementos, passa-se a analisar, de um lado, a dignidade da pessoa humana e o direito fundamental à identidade genética da criança, e, de outro, a liberdade, a integridade física e o direito de não produzir prova contra si mesmo do suposto pai. Ao final da ponderação entre esses direitos fundamentais, deve-se decidir qual deles deve prevalecer.

Nesse contexto, inicialmente se poderia argumentar que o direito à identidade genética se concretizaria na medida em que, uma vez se recusando a fazer o teste de DNA, o investigado estaria assumindo o ônus processual de ser reconhecido pai, em razão da presunção relativa de veracidade que milita em seu desfavor. Por uma análise superficial, sem analisar o conteúdo desses direitos fundamentais, eventualmente se poderia chegar a uma conclusão dessas.

No entanto, caso se analise o conteúdo desse direito, dando-se prevalência à substância e não à forma, chegar-se-á à conclusão de que a via desse ônus processual não é adequada para garantir o núcleo essencial do direito fundamental à verdadeira identidade genética, pois esta não é efetivamente demonstrada pela omissão do investigado em realizar o exame de DNA. Como direito indisponível que é, a paternidade de uma pessoa não pode ser reconhecida com base numa ficção jurídica, em uma presunção legal, pelo simples não cumprimento de um ônus processual pelo réu, que, de forma irresponsável, nega-se a fazer exame de DNA. O direito fundamental à identidade genética compreende o conhecimento do verdadeiro pai e não a atribuição de qualquer pai à criança.

${ }^{35}$ ALEXY, Robert. Teoria dos Direitos Fundamentais. (trad. Virgílio Afonso da Silva). 2. ed., São Paulo: Malheiros, 2011. p. 120. 
Com a atribuição judicial de paternidade com base numa mera ficção, viola-se o núcleo essencial do direito fundamental à identidade genética, que pressupõe a verdade real e não uma verdade meramente formal ou processual. Aliás, a "constituição" da paternidade com base na mera presunção é capaz de violar ainda mais o direito à identidade genética, pois, além de poder atribuir um falso pai, ainda se estaria impedindo que a criança buscasse o seu verdadeiro pai.

Assim, o princípio da proporcionalidade descarta a presunção legal de paternidade - em razão da recusa do suposto pai de fazer o exame de DNA -, pois tal mecanismo processual é inadequado para garantir o direito fundamental à verdadeira identidade biológica.

De outro lado, o mecanismo da realização do exame de DNA, mesmo mediante condução coercitiva, seria adequado para proteger o direito fundamental à verdadeira identidade biológica do ser. Com efeito, tal exame genético é capaz de demonstrar a paternidade e a maternidade em percentual próximo a $100 \%(99,99999997 \%)$, o que representa certeza científica.

Nesse ínterim, também se observa que a realização do teste de DNA é necessária, pois é a única forma de realmente demonstrar a paternidade, já que a presunção relativa de paternidade, ônus processual imposto, não satisfaz o conteúdo do direito fundamental à verdadeira identidade genética, podendo, inclusive, ser objeto de ação rescisória, como já admitiu o STF, além de restar sempre a dúvida sobre a verdadeira paternidade.

Ademais, na sociedade contemporânea, onde há uma obsessão pelo efêmero, são cada vez mais numerosos os casos de filhos gerados em relações eventuais. Por conseguinte, também são crescentes os casos de ações investigatórias de paternidade improcedentes, por exame de DNA negativo, em que a genitora da criança afirmava categoricamente que o investigado era o pai e, depois do exame, vem ajuizar ação investigatória de paternidade contra outra(s) pessoa(s). Vale dizer, o ônus da presunção da paternidade ao investigado que se nega a produzir a prova não garante nem minimamente 0 direito fundamental à verdadeira identidade genética, pois o exame de DNA é a única forma de se atestar com segurança a paternidade. ${ }^{36}$

\footnotetext{
${ }^{36}$ Conforme Andréa Galiza, "Não há dúvida, aqui, de que a medida de condução coercitiva é adequada ou idônea para garantir o direito ao conhecimento da origem genética, tendo em vista a eficácia razoalvelmente comprovada do exame, fato este destacado em diversos momentos da decisão. Entretanto, seria ela necessária? (...) Contudo, a 'confissão ficta' não estabelece a verdade. Pelo menos não uma verdade 'científica' 'possível e suficiente para as demandantes, de modo a esclarecer quem, de fato, seria o seu pai verdadeiro. Sairiam do processo de investigação com uma condenação do demandado, mas sem o mais importante para garantir o direito à sua identidade, que é a certeza de quem é seu pai. Portanto, a solução da confissão ficta não representa meio igualmente idôneo para a garantia do direito fundamental ao conhecimento da origem genética. Isso, apenas o exame razoavelmente garantiria. A confissão ficta e uma possível condenação não são suficientes para a completa realização do direito à identidade. Ela pode até resolver aspectos patrimoniais envolvidos nesse direito, contudo as questões mais importantes, as questões morais, com suas importantes repercussões psicológicas, continuariam sem solução:
} 
Logo, para a concretização do direito fundamental à identidade genética, a realização do teste de DNA é realmente necessária.

No entanto, aplicando-se o princípio da proporcionalidade, deve-se, além de analisar a necessidade e a adequação (idoneidade da medida), também verificar qual direito deve prevalecer aferindo-se a proporcionalidade em sentido estrito.

Assim, fazendo-se um juízo de proporcionalidade em sentido estrito, observa-se que o direito à integridade corporal não será violado no seu núcleo essencial, haja vista que a intervenção é mínima, não sendo necessário nem mesmo uma picada no dedo para retirada de uma gota de sangue, pois os métodos científicos atuais permitem o referido exame com uma ínfima intervenção na pessoa, com a coleta da saliva ou do fio de cabelo.

Ademais, não se pode dizer que seria cruel levar o suposto pai "conduzido sob vara" ou em "uma camisa de força", palavras fortes, de uso retórico, que foram utilizadas no HC 71373/RS, de 1994, apenas para tentar travestir a condução coercitiva com uma feição que ela não tem. O direito deve ser interpretado racionalmente de acordo com o mundo vivencial e não com a metafísica de um mundo imaginário, criando-se personagens ou contextos que não existem.

Quando se determina a condução coercitiva - e isso ocorre todos os dias, como, por exemplo, na condução de testemunhas -, o oficial de justiça se apresenta ao conduzido e lhe explica a situação, bem como a necessidade de conduzi-lo, o que normalmente não encontra resistência.

Assim, caso fosse determinada a condução coercitiva para realização de exame de DNA, diante da força da decisão judicial, o conduzido, na grande maioria dos casos, acompanharia sem resistência o oficial de justiça, sem que se precisasse de qualquer outra medida (como a força policial), sendo imaginária, ilusória e falaciosa qualquer tentativa de vitimizar o réu ao argumento de que seria levado "sob vara" ou com uma "camisa de força".

Nesse sentido, é inimaginável que cortar um fio de cabelo do investigado ou pedir para que ele excrete um pouco de saliva seja demasiado interventivo na sua integridade corporal. ${ }^{37}$ Logo, pela proporcionalidade em sentido estrito,

as filhas saber-se-iam, ainda, sem pai verdadeiro. Some-se a isso outro aspecto importante: restaria insatisfeito um interesse de origem genética para fins de saúde. (...) Assim, a solução da confissão ficta seria menos danosa, sim, ao direito à livre disposição do corpo invocado pelo réu, contudo, inadequada à garantia do direito à identidade física oposto pelas filhas." (GALIZA, Andréa Karla Amaral da. Direitos Fundamentais nas Relações entre Particulares: Teoria e jurisprudência do Supremo Tribunal Federal. Belo Horizonte: Fórum, 2011. p. 176).

${ }_{37}$ Segundo Pedro Welter Belmiro, "(...) se é desumano, vexatório e ofensivo à dignidade humana a coleta de fio de cabelo, de uma gota de saliva, do esperma ou do sangue do investigado, muito mais ofensivo à dignidade humana do filho é a impossibilidade de conhecer a paternidade biológica, que é um direito de personalidade natural e constitucional, cuja negativa também é ofensiva à dignidade humana e cidadania. (...) É por isso que sustentamos a tese de que não se pode presumir a paternidade, ainda mais com negativa em se submeter a exame genético. 
observa-se que a condução coercitiva para realização de exame de DNA não atinge o núcleo essencial do direito à integridade corporal, haja vista que a intervenção não exige qualquer lesão ao corpo, ou ao menos essa intervenção é mínima.

De outro lado, conduzir o suposto pai a fornecer material genético para o exame de DNA, por ser o meio necessário e adequado, é a única forma de efetivamente proteger o direito fundamental à verdadeira identidade genética. Caso não haja o referido exame, julgando-se a ação sem esse meio de prova, estar-se-ia violando o núcleo essencial do direito fundamental à verdadeira identidade genética, pois ele não é protegido pela simples presunção legal.

Também não se pode argumentar que a condução coercitiva para fornecimento de material genético deva ser obstada pelo direito à liberdade. Primeiramente, porque a condução coercitiva é meio amplamente admitido no direito processual para oitiva de testemunha, que tem constrita a sua liberdade em nome da verdade processual; em segundo lugar, porque não se pode admitir que haja violação a um direito fundamental - no caso, ao direito fundamental à identidade genética - em nome de uma liberdade do vazio.

De outro lado, também é inaplicável ao caso o direito de não ser obrigado a produzir prova contra si mesmo, amplamente difundido no direito processual penal. Este não é um direito expresso na Constituição Federal e foi desenvolvido pela doutrina processual penal. Segundo tal princípio, um indiciado em inquérito policial ou um acusado no processo penal não podem ser obrigados a produzir prova contra si mesmo, vale dizer, a prova contra si somente poderia ser produzida com a sua concordância ou sem a sua participação. No entanto, na relação jurídica do processo penal, tem-se, de um lado, o cidadão e, de outro, o Estado, sendo que este possui uma ampla estrutura para produzir a prova sem a participação do acusado. Logo, a relação jurídica processual desenvolvida no processo penal é totalmente diferente da relação jurídica processual da ação investigatória de paternidade. No processo penal, vigora o princípio do in dubio pro reo, enquanto o direito da criança e do adolescente é informado pelo Princípio do Melhor Interesse da Criança (The Best Interest of the Child). Nesse ínterim, não é válido afirmar, com base nesses fundamentos, que a condução coercitiva seria vedada no caso, sobretudo porque visa a garantir mais do que uma prova processual, pois é a única forma de concretizar o direito fundamental à identidade genética.

$\mathrm{Na}$ relação entre a criança e o suposto pai, este carrega consigo o único meio de prova capaz de demonstrar a verdadeira identidade biológica. Logo, dentro da relação jurídica processual de uma ação investigatória de paternidade,

\footnotetext{
No caso, deve-se conduzir coercitivamente o investigado, mas jamais reconhecer uma paternidade biológica com base em simples negativa de realizar um exame de sangue ou uma entrega de um fio de cabelo, sob pena de grave ofensa ao art. 227 da CF e art. 27 do ECA, que determinam a busca incansável da verdade real da filiação biológica." (BELMIRO, Pedro Welter. Possibilidade de Condução Coercitiva do Investigado para fazer Exame Genético. Revista de Direito Privado, São Paulo, v. 2, no 8, p. 24-32, out./dez. 2001).
} 
não há que se falar em hipossuficiência do suposto pai, tampouco em direito de não produzir prova contra si mesmo.

Ademais, não está em questão uma punição ao suposto pai por ter se recusado a fornecer material genético, senão o direito fundamental da criança em saber com segurança quem é o seu pai biológico. Vale dizer, não se trata do exercício da pretensão punitiva estatal, senão do direito fundamental à identidade biológica, uma manifestação da dignidade da pessoa humana. O reconhecimento da paternidade não é e não pode ser visto como uma punição ao suposto pai, senão como um direito fundamental da criança de conhecer a sua ascendência paterna.

De outro lado, não se pode simplesmente dizer que a condução coercitiva para realização de exame de DNA fere a intimidade e a honra. Se é feita uma afirmação dessas, é preciso explicar como e em que medida isso acontece. Fere a intimidade porque o suposto pai vai ser descoberto? Fere a honra porque saberão que aquela pessoa é o pai? Ora, se alguém responder afirmativamente a essas perguntas, também terá de afirmar que um criminoso não pode ser descoberto porque isso feriria a sua honra, que um devedor não poderia se cobrado porque a sua imagem restaria abalada.

Logo, quando se afirma que a condução coercitiva para realização de exame de DNA fere a intimidade e a honra, apenas se está fazendo um discurso vazio de conteúdo. Quando se utiliza uma argumentação assim, prende-se a formas jurídicas vazias, sem analisar o conteúdo dos direitos de que se está falando, como se a utilização de palavras simbolicamente belas pudesse validar o discurso. Caso se sustente algo nesse sentido, é preciso que se explique o porquê e em que medida a condução coercitiva fere a intimidade ou a honra.

Portanto, a aplicação do princípio da proporcionalidade, quando conectada ao mundo real - e não a um mundo ideal ou metafísico -, impõe que o direito fundamental à verdadeira identidade genética prevaleça sobre o interesse do suposto pai de não realizar exame de DNA, já que o teste biológico de paternidade é adequado e necessário para a proteção desse direito fundamental.

\section{CONCLUSÃO}

A decisão do HC 71373/RS, de 10.11.1994, foi construída argumentativamente considerando pressupostos fáticos e o direito existente à época, sendo imprescindível analisá-la reflexivamente à luz do direito vigente e do contexto social, com o atual estágio de desenvolvimento da filosofia e da teoria do direito, das ciências biológicas e da sociedade pós-moderna, a fim de que se verifique se tal entendimento ainda se sustentaria, ou se os pressupostos da referida decisão não são mais válidos, merecendo revisão.

De qualquer sorte, é possível verificar de plano que, à luz da atual teoria dos direitos fundamentais, os argumentos dos votos vencidos na decisão do HC 71373/RS, que entendiam pela obrigatoriedade de realização de exame de DNA, já pareciam ser mais substanciosos. 
Nas decisões que se seguiram envolvendo o direito à identidade genética - especialmente no julgamento da Questão de Ordem na Reclamação 2040, de 21.02.2002, e no julgamento do RE 248869, de 07.08.2003 -, o Supremo Tribunal Federal sinalizou novos contornos ao conteúdo de tal direito fundamental.

No julgamento do RE 363889/DF, em 15.12.2011, no qual o STF decidiu pela prevalência do direito fundamental à identidade genética sobre a coisa julgada, três Ministros da Suprema Corte manifestaram expressamente que a questão da impossibilidade da condução coercitiva do investigado para realizar exame de DNA deveria ser rediscutida, o que definitivamente abriu as portas para nova reflexão sobre a matéria, agora sob um novo paradigma de direito.

No atual paradigma do direito, que tem sido chamado por alguns de pós-positivismo, não se admite mais o decisionismo do positivismo jurídico que fora utilizado outrora. De acordo com o pós-positivismo, o direito não é metafísico, senão criado e recriado pela mente humana e pela sociedade no ambiente público.

Assim, quando o julgador está diante de um caso difícil, deve observar o conteúdo dos direitos fundamentais em conflito, para decidir com base num direito discursivo e vivencial, considerando os valores e os direitos que são mais caros para a sociedade.

No plano das regras jurídicas, observa-se que inexiste qualquer vedação - mas tampouco permissão expressa - para a condução coercitiva para realização de teste de DNA, estando-se diante da colisão de direitos fundamentais e de um caso difícil. Assim, a solução jurídica não pode ser dada pelo silogismo, exigindo-se do intérprete e do julgador que construam argumentativamente a decisão à luz do ordenamento jurídico vigente e considerando os direitos fundamentais em conflito.

Portanto, observa-se que, colocando-se, de um lado da balança, os conteúdos dos direitos à liberdade, à privacidade, à integridade física e de não produzir prova contra si mesmo, e, de outro, os conteúdos do direito fundamental à identidade genética e da dignidade da pessoa humana, fica claro que estes dois últimos direitos fundamentais devem prevalecer.

Com efeito, determinando-se a condução coercitiva para realização de exame de DNA, a interferência nos direitos à liberdade, à privacidade, à integridade física, se existente, é muito fraca; de outro lado, a proteção da dignidade da pessoa humana e do direito fundamental à identidade genética é muito forte, para não dizer que é a única forma de proteger este direito fundamental.

Por todas essas razões, a condução coercitiva do réu para coletar material genético para fazer exame de DNA é a medida adequada e necessária para garantir o núcleo essencial do direito fundamental à identidade genética, direito que deve prevalecer sobre o interesse do investigado de não ser conduzido coercitivamente. 
Portanto, conclui-se que se está diante do fenômeno da mutação constitucional, pois, passados 18 (dezoito) anos da decisão do STF no HC 71373/RS, o direito fundamental à identidade genética ganha uma nova concepção, conteúdo e conformação no ordenamento jurídico, impondo que, em caso de recalcitrância, seja determinada a condução coercitiva do suposto pai para a realização de exame de DNA.

\section{REFERÊNCIAS BIBLIOGRÁFICAS}

ALEXY, Robert. Teoria dos Direitos Fundamentais. (trad. Virgílio Afonso da Silva). 2. ed., São Paulo: Malheiros, 2011.

BRASIL. Supremo Tribunal Federal. HC 71373/RS, Relator: Min. Francisco Rezek, Relator p/ Acórdão: Min. Marco Aurélio. Tribunal Pleno. Julgado em 10.11.1994, DJ 22.11.1996.

BRASIL. Supremo Tribunal Federal. Rcl 2040 QO. Relator: Min. Néri da Silveira. Tribunal Pleno. Julgado em 21.02.2002, DJ 27.06.2003, p. 31.

BRASIL, Supremo Tribunal Federal. RE 248869. Relator: Min. Maurício Corrêa. Segunda Turma. Julgado em 07.08.2003. DJ 12.03.2004, p. 38.

BRASIL, Supremo Tribunal Federal. RE 363889. Relator: Min. Dias Toffoli. Tribunal Pleno. Julgado em 02.06.2011. Acórdão Eletrônico Repercussão Geral - Mérito DJe-238, divulg. 15.12.2011, public. 16.12.2011.

BARROSO, Luís Roberto. Constituição, Democracia de Supremacia Judicial: Direito e política no Brasil contemporâneo. Revista de Direito de Estado, Rio de Janeiro, a. 4, no 6, p. 3-42, out./ dez. 2009.

BELMIRO, Pedro Welter. Possibilidade de Condução Coercitiva do Investigado para fazer Exame Genético. Revista de Direito Privado, São Paulo, v. 2, nº 8, p. 24-32, out./dez. 2001.

CALSAMIGLIA, Albert. Postpositivismo. Doxa, 21, nº 1, p. 209-220, 1998.

CARVALHO NETTO, Menelick de; SCOTTI, Guilherme. Os Direitos Fundamentais e a (in)certeza do Direito: A produtividade das tensões principiológicas e a superação do sistema de regras. Belo Horizonte: Fórum, 2011.

CASTRO, Marcus Faro de. Formas Jurídicas e Mudança Social: Interações entre o direito, a filosofia, a política e a economia. São Paulo: Saraiva, 2012.

DIAS, Maria Berenice. Manual do Direito das Famílias. 2. ed., Porto Alegre: Livraria do Advogado, 2005.

DWORKIN, Ronald. Levando os Direitos a Sério. (trad. Nelson Boeira). 3. ed., São Paulo: Martins Fontes, 2010.

. O Império do Direito. (trad. Jefferson Luiz Camargo). 2. ed., São Paulo: Martins Fontes, 2007.

FERREIRA FILHO, Manoel Gonçalves. Notas sobre o Direito Constitucional Pósmoderno, em partilhar sobre certo Neoconstitucionalismo à Brasileira. Revista de Direito Administrativo, Rio de Janeiro, v. 250, p. 151-167, jan./abr. 2009.

GALIZA, Andréa Karla Amaral da. Direitos Fundamentais nas Relações entre Particulares: Teoria e jurisprudência do Supremo Tribunal Federal. Belo Horizonte: Fórum, 2011. 
HABERMAS, Jürgen. Era das Tradições. (trad. Flávio Siebeneichler). Rio de Janeiro: Tempo Brasileiro, 2003.

. Direito e Democracia: Entre faticidade e validade. v. 1. (trad. Flávio Beno Siebeneichler). Rio de Janeiro: Tempo Brasileiro, 2010.

HIRONAKA, Giselda Maria Fernandes Novaes. Os Contornos Jurídicos da Responsabilidade Afetiva na Relação entre Pais e Filhos além da obrigação legal de caráter material. In: HIRONAKA, Giselda Maria Fernandes Novaes. (Coord.). A Outra face do Poder Judiciário: Decisões inovadoras e mudanças de paradigmas. Belo Horizonte: Del Rey, 2005. p. 446-500.

NADER, Paulo. Filosofia do Direito. 19. ed., Rio de Janeiro: Forense, 2010.

REALE, Miguel. Filosofia do Direito. 5. ed., São Paulo: Saraiva, 2003. . Lições Preliminares de Direito. 27. ed., São Paulo: Saraiva, 2002.

RORTY, Richard. Contingência, Ironia e Solidariedade. (trad. Vera Ribeiro). São Paulo: Martins Fontes, 2007. 